\title{
TESTOSTERONE PRODUCTION RATES IN NORMAL ADULTS
}

\author{
By STANLEY G. KORENMAN, HILDEGARD WILSON, AND \\ MORTIMER B. LIPSETT
}

(From the Endocrinology Branch, National Cancer Institutc, Bcthesda, Md.)

(Submitted for publication May 13, 1963 ; accepted July 22, 1963)

The investigation of clinical and physiological problems related to androgen production has been hampered by lack of an adequate measure of testosterone production. As one approach to this problem, Finkelstein, Forchielli, and Dorfman (1) developed a sensitive method for the measurement of free testosterone in plasma. The subsequent identification of testosterone in the urine (2) as the glucuronoside (3) provided a unique metabolite for the estimation of testosterone production rate by the isotope-dilution method. One such study, using an isotope-derivative method to quantitate testosterone, was briefly reported by Hudson, Coghlan, Dulmanis, and Ekkel (4).

We have measured urinary testosterone by an adaptation of the fluorescence reaction described by Wilson (5). This has facilitated the use of the isotope-dilution method for the measurement of testosterone production rates in man.

\section{MATERIALS AND METHODS}

L.S., L.M., G.S., R.S., J.S., C.Z., and M.G. were healthy young adult volunteers C.S. was a 27 -year-old white woman in complete remission after treatment for metastatic choriocarcinoma. Regular menses had occurred for the 6 months before study. E.H. was a 27 -year-o'd Negro woman with normal menstrual function admitted for treatment of local recurrence of carcinoma of the breast.

Absolute ethanol 1 was redistilled by the method of Peterson and his associates (6). Water was glass-distilled after the addition of a few crystals of $\mathrm{KMnO}_{4}$. $n$-Hexane, ether, chloroform, and methanol were prepared as previously described $(7,8)$. Ligroin ${ }^{2}$ was prepared exactly like $n$-hexane; on redistillation, the fraction boiling from $103^{\circ} \mathrm{C}$ to $106^{\circ} \mathrm{C}$ was collected. Benzene, ethyl acetate, and acetic anhydride were redistilled. Pyridine was allowed to stand overnight over calcium hydride and then redistilled under anhydrous conditions. Sulfuric acid, reagent grade, ${ }^{3}$ was used as supplied.

1 U. S. Industrial Chemicals, Inc., Baltimore, Md.

2 Eastman Kodak \#P-1628, Eastman Kodak Co., Rochester, N. Y.

${ }^{3}$ Fisher Scientific Corp., Boston, Mass.
Silica gel $G^{4}$ was washed twice with absolute ethanol and once with redistilled ethanol. After the third wash, the wet powder was heated overnight in an oven at $100^{\circ} \mathrm{C}$ and then stored at room temperature in a desiccator. An alcohol eluate of a $10-\mathrm{g}$ sample of the powder should give no colored residue.

The steroids ${ }^{5}$ used were obtained from commercial sources. Testosterone and testosterone acetate were recrystallized, and the melting points agreed with reported values. Other materials used were human folliclestimulating hormone (FSH) (potency, $0.1 \mathrm{ml}=1 \mathrm{U}$ $\mathrm{NIH} \mathrm{FSH-S1)} \mathrm{contaminated} \mathrm{with} \mathrm{a} \mathrm{small} \mathrm{amount} \mathrm{of}$ luteinizing hormone, human chorionic gonadotropin (HCG), ${ }^{6}$ and testosterone-4-C $\mathrm{C}^{14} 7$ (77 $\mu \mathrm{c}$ per $\left.\mathrm{mg}\right)$, which was chromatographed in systems A2 and B6 before use.

Partition column chromatography. The technique previously described (7) was modified so that extracts of 1.5 days' urine could be resolved on a single column. The glass tube was $48 \mathrm{~mm}$ i.d. and $30 \mathrm{~mm}$ long with a 55:50 outer joint at the top. Solvent systems are shown in Table I.

Seventy $\mathrm{g}$ of silica-alumina catalyst, used as supplied, was mixed with $43 \mathrm{ml}$ stationary phase $A$ and packed in about $140 \mathrm{ml}$ mobile phase A previously poured into the column. The dried urine extract was applied with successive portions of $1.2,0.6$, and $0.3 \mathrm{ml}$ stationary phase A, each mixed with an equal volume of mobile phase $\mathrm{A}$. Each transfer was preceded by placing layers of 2, 1, and $0.5 \mathrm{~g}$ dry silicate on the column. To develop the column, the successive solvents were allowed to drop freely from a funnel onto a constant solvent head of $75 \mathrm{ml}$.

The third eluate (B1, Table I) was standardized to contain all the testosterone. Further eluates were collected only for studies of more polar metabolites.

Thin-layer chromatography. Thin layer plates $(20 \times$ $20 \mathrm{~cm}$ ) were coated with silica gel $\mathrm{G}$, activated by heating in an oven at $100^{\circ} \mathrm{C}$ for 40 minutes, and stored at room temperature. A coating of $500 \mu$ thickness was used for column effluents, and $200 \mu$ was used for purer fractions. The developing systems used were B6, benzene: ethyl acetate $(6: 4)$ and $B 8$, benzene: ethyl acetate $(8: 2)$. Appropriate areas were eluted 3 times with $2 \mathrm{ml}$ absolute ethanol.

\footnotetext{
4 Brinkmann Instruments, Great Neck, N. Y.

5 The chemical and trivial names of all steroids used are given in Table IV.

${ }^{6}$ Ayerst Laboratories, New York. N. Y.

${ }^{7}$ New England Nuclear Corp., Boston, Mass.
} 
TABLE I

Solvent systems and fractions collected from the partition column

\begin{tabular}{|c|c|c|c|c|c|c|c|c|}
\hline \multirow[b]{2}{*}{ System } & \multirow[b]{2}{*}{ Composition } & \multicolumn{4}{|c|}{ Volume } & \multirow[b]{2}{*}{ Eluate } & \multirow{2}{*}{$\begin{array}{l}\text { Volume } \\
\text { collected }\end{array}$} & \multirow[b]{2}{*}{ Typical component } \\
\hline & & Hexane & $\mathrm{CHCl}_{3}$ & $\mathrm{EtOH}$ & $\mathrm{H}_{2} \mathrm{O}$ & & & \\
\hline & & $m l$ & $m l$ & $m l$ & $m l$ & & $m l$ & \\
\hline A & $\begin{array}{l}2 \% \mathrm{CHCl}_{3} \\
98 \% \text { Hexane }\end{array}$ & 392 & 8 & 50 & 50 & $\begin{array}{l}\text { A1 } \\
\text { A2 }\end{array}$ & $\begin{array}{r}100 \\
80\end{array}$ & $\begin{array}{l}16 \text {-androstene- } 3 \alpha \text {-ol } \\
\mathrm{C}_{19} \mathrm{O}_{2}-17 \text {-ketosteroids }\end{array}$ \\
\hline \multirow[t]{2}{*}{$\mathrm{B}$} & \multirow{2}{*}{$\begin{array}{l}15 \% \mathrm{CHCl}_{3} \\
85 \% \text { Hexane }\end{array}$} & \multirow[t]{2}{*}{340} & \multirow[t]{2}{*}{60} & \multirow[t]{2}{*}{50} & \multirow[t]{2}{*}{50} & B1 & 200 & Testosterone, epitestosterone, \\
\hline & & & & & & $\mathrm{B} 2$ & 300 & $\begin{array}{l}\mathrm{C}_{19} \mathrm{O}_{3}-17-\mathrm{KS} \text {, pregnanetriol, 5-preg- } \\
\text { nenetriol }\end{array}$ \\
\hline $\mathrm{C}$ & $\begin{array}{l}30 \% \mathrm{CHCl}_{3} \\
70 \% \text { Hexane }\end{array}$ & 224 & 96 & 40 & 40 & $\begin{array}{l}\mathrm{C} 1 \\
\mathrm{C} 2\end{array}$ & $\begin{array}{l}200 \\
260^{*}\end{array}$ & $\begin{array}{l}\text { Tetrahydro S } \\
\text { Tetrahydro E }\end{array}$ \\
\hline $\mathrm{D}$ & $\begin{array}{l}60 \% \mathrm{CHCl}_{3} \\
40 \% \text { Hexane }\end{array}$ & 160 & 240 & 50 & 50 & $\begin{array}{l}\text { D1 } \\
\text { D2 }\end{array}$ & $\begin{array}{l}250 \\
150 \dagger\end{array}$ & Tetrahydro F, cortolone \\
\hline $\mathrm{E}$ & $\begin{array}{l}80 \% \mathrm{CHCl}_{3} \\
20 \% \text { Hexane }\end{array}$ & 40 & 160 & 25 & 25 & $\mathrm{E}$ & 250 & $\begin{array}{l}\text { Cortol } \\
\text { More polar ketols }\end{array}$ \\
\hline
\end{tabular}

* After collecting $200 \mathrm{ml}$ of $\mathrm{C} 2$, the column head is allowed to run down for a further $60 \mathrm{ml}$ retaining a $15-\mathrm{ml}$ head. $\dagger$ Eluates D2 and E contain overlapping components and are therefore combined.

Paper chromatography. Whatman 1 filter paper was washed as previously described (8). Chromatograms were equilibrated for at least 3 hours and developed for 16 hours in Bush system A2, ligroin: methanol: water $(100: 70: 30)$.

Radioactive counting. All counting was done in a Packard Tri-Carb liquid scintillation spectrometer, model 314EX. Dry steroid samples were dissolved in $5 \mathrm{ml}$ of toluene containing $0.4 \%$ diphenyloxazole (PPO) and $0.005 \%$ 1,4-bis-2-(5-phenyloxazolyl)benzene (POPOP). ${ }^{8}$ Discriminator and gain settings were such as to give an efficiency of $74 \%$ for $\mathrm{C}^{14}$. Raw urine samples were counted in the polyether 611 phosphor of Davidson and Feigelson (9) with $1 \mathrm{ml}$ of urine, $1 \mathrm{ml}$ of water, and 10 to $14 \mathrm{ml}$ of phosphor assuring a one-phase system without crystallization of dioxane. Quenching was estimated by adding $0.1 \mathrm{ml}$ of phosphor containing a known number of counts to each sample. $\mathrm{C}^{14}$ efficiency in this system was $25 \%$. Sufficient counts were collected to give a $\mathrm{SE}$ of less than $5 \%$ at the $95 \%$ confidence limits unless specifically stated.

Gas-liquid chromatography. ${ }^{9}$ A 6-foot spiral glass column with a $3.4 \mathrm{~mm}$ i.d. was prepared with $1 \%$ silicone polymer resin SE-30 by the method described by Haahti (10). A Lovelock radium-foil Argon ionization detector was operated at $1,000 \mathrm{v}$ with Argon pressure at 20 pounds per square inch, resulting in a flow rate of $25 \mathrm{ml}$ per minute. The column temperature was $207^{\circ} \mathrm{C}$ with detector and flash heater at $250^{\circ} \mathrm{C}$. Under these conditions, $0.2 \mu \mathrm{g}$ of testosterone gave a peak height of 21 $\mathrm{mm}$ with a retention time of 0.51 relative to cholestane.

Fluorometric assay. Sulfuric acid reagent was freshly prepared by adding 8 parts concentrated $\mathrm{H}_{2} \mathrm{SO}_{4}$ to 2 parts of $90 \%$ redistilled ethanol. Triplicate samples of the

\footnotetext{
8 Pilot Chemicals, Watertown, Mass.

${ }^{9}$ Carried out in an apparatus designed by the Glowall Corp., Glenside, $\mathrm{Pa}$.
}

fractions to be assayed were evaporated to dryness in acid-washed $10-\times 75-\mathrm{mm}$ test tubes and heated for 12 minutes in a $56^{\circ} \mathrm{C}$ water bath after the addition of 0.5 $\mathrm{ml}$ of sulfuric acid reagent. The tubes were then plunged into an ice bath and the samples diluted with $0.75 \mathrm{ml}$ of 95\% redistilled ethanol and mixed thoroughly on a Vortex mixer. ${ }^{10}$ Fluorescence was determined in an Aminco-Bowman spectrophotofluorometer with a 1-P-21 RCA photomultiplier tube and an Osram xenon lamp. Meter multiplier gain was .01 . Slit widths were $1 / 32$ inch for the $0.18-\mathrm{ml}$ quartz microcuvettes. The excitation and fluorescence maxima were $475 \mathrm{~m} \mu$ and $530 \mathrm{~m} \mu$ respectively for testosterone. Alcohol and reagent blanks always read less than $20 \%$ of the value of the lowest standard. A standard curve was constructed for each assay from duplicate standards ranging from 0.020 to $0.160 \mu \mathrm{g}$.

Comments on method. The purification steps outlined above were necessary to eliminate contaminants found in the silica gel $\mathrm{G}$, the water, and the ethanol. A plateau of fluorescence intensity was obtained between 70 to $90 \%$ $\mathrm{H}_{2} \mathrm{SO}_{4}$ concentration and between 8 to 16 minutes heating time. Although there was a rapid decay at room temperature, fluorescence was stable for 2 hours in an ice bath and was unaffected by normal illumination. Fluorescence was linear between 0.010 and $0.750 \mu \mathrm{g}$ per sample.

Reliability of results. The following studies were performed to demonstrate the reproducibility, accuracy, and sensitivity of the method.

Equal samples of the same final testosterone fraction were measured in 12 successive assays (Table II). According to the criterion of Grubbs (11), the disparate value .154 may be discarded, giving a $\mathrm{SE}$ of the method of 0.0066 , or $6 \%$ at that level.

Samples of final testosterone preparations containing

10 Scientific Industries, Inc., Queens Village, N. Y. 
$0.2 \mu \mathrm{g}$ as measured by fluorescence gave values in close agreement when analyzed by gas chromatography ( $\mathrm{Ta}$ ble III). Moreover, in each instance only the single testosterone peak was seen, suggesting purity of the final fraction.

The fluorescence of a number of steroids including several with mobilities similar to that of testosterone was assayed under these conditions (Table IV). The presence of a double bond in the molecule appeared to be a necessary but not a sufficient requirement for fluorescence. The absence of a characteristic structure for sulfuric acid-induced fluorescence has been noted by other workers (12-14).

Measurement of testosterone production rate. Testosterone-4- $C^{14}(0.3$ to $1 \mu \mathrm{c})$ in less than $0.5 \mathrm{ml}$ absolute ethanol was taken up in 20 to $30 \mathrm{ml}$ of isotonic saline in a syringe and injected intravenously. The syringe was rinsed with the patient's blood. Urine was collected for 3 days and stored at $-14^{\circ} \mathrm{C}$. Hydrolysis was carried out with $\beta$-glucuronidase, ${ }^{11} 400 \mathrm{U}$ per $\mathrm{ml}$ for 72 hours at $37^{\circ} \mathrm{C}, \mathrm{pH}$ 5.0. After acidification to $\mathrm{pH} 0.8$ with $\mathrm{H}_{2} \mathrm{SO}_{4}$, the urine was continuously extracted with ether for 72 hours. The neutral extract was chromatographed on 1 or 2 silicate columns. The fraction containing testosterone was treated with digitonin (8), and the supernatant $3 \alpha$-hydroxy fraction was chromatographed on three $500-\mu$ thin-layer plates in system B6. The testosterone area was eluted, acetylated with acetic anhydride in pyridine, and chromatographed in system B8. It was then saponified (15) and chromatographed on paper in system A2. Testosterone was located by scanning in a Nuclear-Chicago paper strip scanner model C-100 B and, when possible, by ultraviolet absorption.

After rechromatography in system B6, samples of the testosterone eluate were assayed for fluorescence and counted. When possible, a portion was taken for gasliquid chromatography. To establish constancy of SA in the present studies, each specimen was reacetylated, resaponified, chromatographed in systems B8 and B6, respectively, and then assayed and counted. Testosterone production rate was estimated by the use of the formula: production rate $=$ radioactivity given $/ S A$ of urinary testosterone $\times$ day's.

The coefficient of variation for the procedure was calculated by analysis of variance after a logarithmic transformation of the data in Tables VI and VII, and a value of $11 \%$ was obtained (16). The logarithmic transformation was needed because sample variance was proportional to the means of the data pairs. Thus variation of results beyond $22 \%$ was probably not due to experimental error. About one-half of the variance was due to C.Z., in whom a gross discrepancy in the second value was obtained.

\section{RESULTS}

Recovery of administered radioactivity. In 5 separate studies, 66 to $80 \%$ of the administered

\footnotetext{
11 Ketodase, Warner-Chilcott Laboratories, Morris Plains, N. J.
}

TABLE II

Reproducibility of fluorometric assay for testosterone

\begin{tabular}{cccc}
\hline \hline & $\mu g$ & $\mu g$ & $\mu g$ \\
.130 & .114 & .133 & .128 \\
.126 & .128 & .119 & .114 \\
$.154^{*}$ & .116 & .127 & .124 \\
Mean .1235 & & & \\
SD .0066 & & & \\
\hline
\end{tabular}

* This value is an outlier at the $99 \%$ confidence limits (11)

$\mathrm{C}^{14}$ was excreted within 3 days (Table V). Ninety-six to $99 \%$ of this radioactivity was excreted within 48 hours of injection, indicating that a 2-day urine collection is adequate for estimation of testosterone production rates.

Testosterone production rates (Table VI) ranged from 4 to $11.8 \mathrm{mg}$ per day in the men and were increased by 23,58, and $170 \%$ in 3 cases after the administration of $1,000 \mathrm{U}$ of $\mathrm{HCG}$ for 5 days. There was no apparent difference between the base-line values in the 3 men receiving corticosteroids $^{12}$ and the 2 untreated men.

TABLE III

Comparison of the testosterone content of purified urine fractions as determined by gas-liquid chromatography and by fuorescence

\begin{tabular}{lccc}
\hline \hline Patient & Period & $\begin{array}{c}\text { Testosterone by } \\
\text { fluorescence }\end{array}$ & $\begin{array}{c}\text { Testosterone by gas } \\
\text { chromatography }\end{array}$ \\
\hline & & $\mu g$ & $\mu g$ \\
L.S. & 1 & .20 & .22 \\
L.S. & 2 & .20 & .20 \\
L.M. & 1 & .20 & .22 \\
G.S. & 1 & .20 & .21 \\
G.S. & 2 & .20 & .21 \\
R.S. & & .20 & .19 \\
\hline
\end{tabular}

In 4 women, 2 receiving corticosteroids, testosterone production rates ranged from 0.94 to 2.8 mg daily (Table VII). There was an increase after FSH administration and a doubling of baseline values when $\mathrm{HCG}$ was added. These increases were greater than the experimental error of the method $(\mathrm{p}<.05)$.

12 Corticoids were given to 5 subjects in this study when we were attempting to measure testosterone secretion rates using an early model of androgen metabolism described by Vande Wiele and Lieberman (17). 
TABLE IV

Fluorogenicity of various steroids*

\begin{tabular}{|c|c|c|}
\hline Chemical name & Trivial name & $\begin{array}{l}\text { Relative \% fluorescence } \\
\text { (testosterone }=100 \%)\end{array}$ \\
\hline 4-Androstene-17 $\beta$-ol-3-one & Testosterone & 100 \\
\hline 4-Androstene-17 $\alpha$-ol-3-one & Epitestosterone & 100 \\
\hline 1-Androstene-3,17-dione & & 67 \\
\hline $17 \beta$-Acetoxy-4-androstene-3-one & Testosterone acetate & 60 \\
\hline 1-Androstene-17 $\beta$-ol-3-one & & 50 \\
\hline 4-Androstene-3,17-dione & Androstenedione & 33 \\
\hline 4 -Androstene- $3 \beta, 17 \beta$-diol & & 30 \\
\hline 4-Pregnene-11 $1 \beta, 17 \alpha, 21$-triol-3,20-dione & Cortisol & 20 \\
\hline 4-Pregnene-11 $\beta, 21$-diol-3,20-dione & Corticosterone & 20 \\
\hline 4-Pregnene-21-ol-3,20-dione & Desoxycorticosterone & 15 \\
\hline 5 -Androstene- $3 \beta, 17 \beta$-diol & & 10 \\
\hline 4 -Androstene- $6 \beta$-ol-3,17-dione & & 2 \\
\hline 16-Androstene-3 $\beta$-ol & & 2 \\
\hline 4-Pregnene-17 $\alpha$-ol-3,20-dione & $17 \alpha$-Hydroxyprogesterone & 0 \\
\hline 4-Pregnene-17a,21-diol-3,11,20-trione & Cortisone & 0 \\
\hline $5 \alpha$-Androstane-3 $\alpha$-ol-17-one & Androsterone & 0 \\
\hline $5 \beta$-Androstane-3 $\alpha$-ol-17-one & Etiocholanolone & 0 \\
\hline $5 \alpha$-Androstane- $3 \beta$-ol-17-one & Epiandrosterone & 0 \\
\hline 5-Androstene-3 $\beta$-ol-17-one & Dehydroepiandrosterone & 0 \\
\hline $5 \alpha$-Androstane- $3 \alpha, 17 \beta$-diol & Androstanediol & 0 \\
\hline $5 \beta$-Androstane- $3 \alpha, 17 \beta$-diol & Etiocholanediol & 0 \\
\hline Pregnane- $3 \alpha, 20 \alpha$-diol & Pregnanediol & 0 \\
\hline Pregnane-3 $\alpha, 17 \alpha, 20 \alpha$-triol & Pregnanetriol & 0 \\
\hline 4 -Androstene-11 $\beta$-ol-3,17-dione & $11 \beta$-Hydroxyandrostenedione & 0 \\
\hline 1,4-Androstadiene-17 $\beta$-ol-3-one & & 0 \\
\hline $5 \alpha$-Androstane-17 $\beta$-ol-3-one & & 0 \\
\hline $5 \beta$-Androstane-17 $\beta$-ol-3-one & & 0 \\
\hline
\end{tabular}

* 0.2 and $0.5 \mu \mathrm{g}$ of steroid were assayed by the method described in the text. The fluorescence of testosterone is set at $=100 \%$.

\section{DISCUSSION}

Although fluorescence of testosterone in $\mathrm{H}_{2} \mathrm{SO}_{4}$ has been noted previously (12-14), our procedure is the first quantitative method applicable to submicrogram amounts of the steroid. The reaction is relatively specific, although two potentially contaminating steroids, androstenedione and epitestosterone, are also highly fluorogenic (Table IV). The finding of a single peak on gas-liquid chromatography ruled out the presence of androstenedione, which was also separated on all the chromatographic systems used. Epitestosterone, however, and its acetate migrate in $\mathrm{B} 6$ and $\mathrm{B} 8$, respectively, just as testosterone and its acetate. Furthermore, both free steroids have the same retention time in gas-liquid chromatography with the SE-30 column. However, epitestosterone has a mobility 1.5 times that of testosterone in system A2, thus ensuring adequate separation. This is of importance, since we have found epitestosterone in the urine of some of the male subjects in amounts comparable to those of testosterone and have shown that it is not derived from testosterone (18). Therefore double-isotope derivative methods that do not adequately separate testosterone

TABLE $V$

Urinary excretion of radioactivity following testosterone-4-C $C^{14}$ administration

\begin{tabular}{|c|c|c|c|c|c|c|c|}
\hline \multirow[b]{2}{*}{ Patient } & \multirow[b]{2}{*}{ Period } & \multirow{2}{*}{$\begin{array}{l}\text { Radioactivity } \\
\text { administered }\end{array}$} & \multicolumn{3}{|c|}{ Daily recovery of radioactivity } & \multicolumn{2}{|c|}{ Radioactivity recovered } \\
\hline & & & Day 1 & Day 2 & Day 3 & Total & On day 3 \\
\hline & & $d p m$ & $d p m$ & $d p m$ & $d p m$ & $\%$ & $\%$ \\
\hline L.S. & 2 & $9.5 \times 10^{5}$ & \multicolumn{2}{|c|}{$7.1 \times 10^{5}$} & $6.7 \times 10^{3}$ & 75 & 9 \\
\hline L.M. & 2 & $9.5 \times 10^{5}$ & \multicolumn{2}{|c|}{$6.2 \times 10^{5}$} & $4.3 \times 10^{3}$ & 66 & .7 \\
\hline G.S. & 1 & $1.1 \times 10^{6}$ & $7.7 \times 10^{5}$ & $8.2 \times 10^{4}$ & $3.0 \times 10^{4}$ & 80 & 3.4 \\
\hline G.S. & 2 & $1.0 \times 10^{6}$ & $7.0 \times 10^{5}$ & $4.8 \times 10^{4}$ & $3.1 \times 10^{4}$ & 78 & 4.0 \\
\hline C.S. & 3 & $2.3 \times 10^{6}$ & $1.3 \times 10^{6}$ & $3.3 \times 10^{5}$ & $4.5 \times 10^{4}$ & 74 & 2.6 \\
\hline
\end{tabular}


TABLE VI

Teslosterone production rates in five normal men

\begin{tabular}{|c|c|c|c|c|c|c|c|c|}
\hline \multirow[b]{2}{*}{ Patient } & \multirow[b]{2}{*}{ Age } & \multirow[b]{2}{*}{ Period } & \multicolumn{2}{|l|}{ Treatment } & \multirow{2}{*}{$\begin{array}{l}\text { Testosterone } \\
\text { recovered } \dagger\end{array}$} & \multirow[b]{2}{*}{$S A$} & \multirow{2}{*}{$\begin{array}{l}\text { Radioactivity } \\
\text { given }\end{array}$} & \multirow{2}{*}{$\begin{array}{l}\text { Testosterone } \\
\text { production } \\
\text { ratet }\end{array}$} \\
\hline & & & Daily dose & Duration* & & & & \\
\hline \multirow{3}{*}{ I..S. } & years & & & days & $\mu g$ & $d p m$ per $\mu g$ & $d p m$ & $m g$ per day \\
\hline & 21 & 1 & Prednisone, $15 \mathrm{mg}$ & 6 & $\begin{array}{l}38 \\
26\end{array}$ & $\begin{array}{l}56 \\
48\end{array}$ & $6.6 \times 10^{5}$ & $\begin{array}{l}5.9 \\
69\end{array}$ \\
\hline & & 2 & $\begin{array}{l}\text { Prednisone, } 5 \mathrm{mg} \\
\mathrm{HCG}, 1,000 \mathrm{U}\end{array}$ & $\begin{array}{r}17 \\
8\end{array}$ & $\begin{array}{l}60 \\
36\end{array}$ & $\begin{array}{l}70 \\
49 \\
45\end{array}$ & $9.5 \times 10^{5}$ & $\begin{array}{r}9.7 \\
10.5\end{array}$ \\
\hline \multirow[t]{2}{*}{ I...M. } & 26 & 1 & Prednisone, $15 \mathrm{mg}$ & 6 & $\begin{array}{l}22 \\
11\end{array}$ & $\begin{array}{l}82 \\
80\end{array}$ & $6.6 \times 10^{5}$ & $\begin{array}{l}4.0 \\
4.1\end{array}$ \\
\hline & & 2 & $\begin{array}{l}\text { Prednisone, } 5 \mathrm{mg} \\
\mathrm{HCG}, 1,000 \mathrm{U}\end{array}$ & $\begin{array}{r}17 \\
8\end{array}$ & $\begin{array}{l}6 \\
3\end{array}$ & $\begin{array}{l}47 \\
40\end{array}$ & $9.5 \times 10^{5}$ & $\begin{array}{l}10.1 \\
11.9\end{array}$ \\
\hline \multirow[t]{2}{*}{ G.S. } & 21 & 1 & Cortisone, $15 \mathrm{mg}$ & 5 & $\begin{array}{l}29 \\
26\end{array}$ & $\begin{array}{l}31 \\
31\end{array}$ & $1.1 \times 10^{6}$ & $\begin{array}{l}11.8 \\
11.8\end{array}$ \\
\hline & & 2 & $\begin{array}{l}\text { Cortisone, } 15 \mathrm{mg} \\
\mathrm{HCG}, 1,000 \mathrm{U}\end{array}$ & $\begin{array}{r}12 \\
6\end{array}$ & $\begin{array}{l}39 \\
22\end{array}$ & $\begin{array}{l}24 \\
22\end{array}$ & $1.0 \times 10^{6}$ & $\begin{array}{l}13.9 \\
15.2\end{array}$ \\
\hline J.S. & 26 & & & & $\begin{array}{r}13 \\
6\end{array}$ & $\begin{array}{l}120 \\
125\end{array}$ & $2.3 \times 10^{6}$ & $\begin{array}{l}6.4 \\
6.1\end{array}$ \\
\hline R.S. & 23 & & & & $\begin{array}{l}29 \\
18\end{array}$ & $\begin{array}{l}89 \\
90\end{array}$ & $2.3 \times 10^{6}$ & $\begin{array}{l}8.6 \\
8.5\end{array}$ \\
\hline
\end{tabular}

* The production-rate assay was performed during the last 3 days of each medication period.

$\dagger$ Duplicate values represent estimates after repetition of the acetylation and saponification procedure used to isolate testosterone.

from epitestosterone before derivative formation may be subject to considerable error.

Testosterone production rates in five young men ranged between 4 and $11.8 \mathrm{mg}$ daily. Previous indirect estimates have been of the order of 3 to less than $17 \mathrm{mg}$ daily $(17,19,20)$. Using an isotope-dilution technique, Hudson reported values of 4 to $9 \mathrm{mg}$ daily (4). In their recent studies of androgen metabolism, Vande Wiele, MacDonald, Gurpide, and Lieberman (21) estimated a testosterone secretion rate of $6.1 \mathrm{mg}$ and a production rate of $6.9 \mathrm{mg}$ in a normal man.

After administration of testosterone-4- $\mathrm{C}^{14}$, we recovered about one-half of the radioactivity as urinary androsterone and etiocholanolone. With a $50 \%$ conversion of testosterone to these steroids assumed, 2 to $6 \mathrm{mg}$ of 17 -ketosteroids per day were derived from testosterone in the men. This provides direct evidence for the long-held assumption that the higher average ketosteroid excretion in men is due largely to testosterone production.

The prompt increase in testosterone production rates with HCG is interesting in view of the slow and equivocal rise in 17-ketosteroid excretion after administration of comparably low doses of HCG (22). Eik-Nes (23) has shown in the dog that HCG can stimulate the secretion of tes- tosterone in spermatic-vein blood within 1 hour after injection. Since the increment in production of testosterone is a measure of the functional capacity of the testis, the present procedure should provide a substantially more sensitive index of Leydig-cell responsiveness than previous methods. We emphasize that in these few studies the possible roles of biological variability and corticosteroid administration cannot be evaluated.

The low testosterone production rates in the four women studied are consistent with present endocrine concepts. Although the production rates were lower in the two women receiving cortisone, these data are obviously inadequate. It is tempting to suggest, in light of the recent demonstration (21), that androstenedione is an importan precursor of testosterone in women and that the cortisone inhibited adrenal cortical production of androstenedione. Further studies are in progress to answer this question.

Since HCG has been shown to stimulate other ovarian secretions $(24,25)$, and in the absence of satisfactory evidence that HCG can stimulate the adrenal cortex, these data support the hypothesis that HCG stimulates the production of testosterone or one of its precursors by the ovary. During the 5-day period of the study, however, the production rate did not reach the normal male range. 
TABLE VII

Testosterone production rates in four normal women

\begin{tabular}{|c|c|c|c|c|c|c|c|c|}
\hline \multirow[b]{2}{*}{ Patient } & \multirow[b]{2}{*}{ Age } & \multirow[b]{2}{*}{ Period } & \multicolumn{2}{|l|}{ Treatment } & \multirow{2}{*}{$\begin{array}{l}\text { Testosterone } \\
\text { recovered } \dagger\end{array}$} & \multirow[b]{2}{*}{ SA } & \multirow{2}{*}{$\begin{array}{c}\text { Radioactivity } \\
\text { given }\end{array}$} & \multirow{2}{*}{$\begin{array}{c}\text { Testosterone } \\
\text { production } \\
\text { rate† }\end{array}$} \\
\hline & & & Daily dose & Duration* & & & & \\
\hline & years & & & days & $\mu g$ & $d p m$ per $\mu g$ & $d p m$ & $m g$ per day \\
\hline \multirow[t]{3}{*}{ E.H. } & 27 & 1 & Cortisone, $15 \mathrm{mg}$ & 5 & $\begin{array}{l}4.1 \\
2.7\end{array}$ & $\begin{array}{l}890 \\
800\end{array}$ & $2.5 \times 10^{6}$ & $\begin{array}{l}0.94 \\
1.0\end{array}$ \\
\hline & & 2 & $\begin{array}{l}\text { Cortisone, } 15 \mathrm{mg} \\
\text { Human FSH, } 0.4 \mathrm{ml}\end{array}$ & $\begin{array}{r}11 \\
5\end{array}$ & $\begin{array}{l}5.6 \\
.12\end{array}$ & $\begin{array}{l}545 \\
445 \ddagger\end{array}$ & $2.4 \times 10^{6}$ & $\begin{array}{l}1.5 \\
1.8\end{array}$ \\
\hline & & 3 & $\begin{array}{l}\text { Cortisone, } 15 \mathrm{mg} \\
\text { Human FSH, } 0.4 \mathrm{ml} \\
\mathrm{HCG}, 2,000 \mathrm{U}\end{array}$ & $\begin{array}{r}15 \\
9 \\
4\end{array}$ & $\begin{array}{l}5.6 \\
4.5\end{array}$ & $\begin{array}{l}346 \\
390\end{array}$ & $2.5 \times 10^{6}$ & $\begin{array}{l}2.4 \\
2.1\end{array}$ \\
\hline \multirow[t]{3}{*}{ C.S. } & 27 & 1 & Cortisone, $15 \mathrm{mg}$ & 5 & $\begin{array}{l}1.6 \\
.18\end{array}$ & $\begin{array}{l}705 \\
684\end{array}$ & $2.3 \times 10^{6}$ & $\begin{array}{l}1.1 \\
1.1\end{array}$ \\
\hline & & 2 & $\begin{array}{l}\text { Cortisone, } 15 \mathrm{mg} \\
\text { Human FSH, } 0.4 \mathrm{ml}\end{array}$ & $\begin{array}{r}11 \\
5\end{array}$ & $\begin{array}{l}3.0 \\
.20\end{array}$ & $\begin{array}{l}545 \\
505 \ddagger\end{array}$ & $2.4 \times 10^{6}$ & $\begin{array}{l}1.4 \\
1.6\end{array}$ \\
\hline & & 3 & $\begin{array}{l}\text { Cortisone, } 15 \mathrm{mg} \\
\text { Human, FSH } 0.4 \mathrm{ml} \\
\mathrm{HCG}, 2,000 \mathrm{U}\end{array}$ & $\begin{array}{r}15 \\
9 \\
4\end{array}$ & $\begin{array}{l}1.7 \\
.027\end{array}$ & $\begin{array}{l}470 \\
400 \S\end{array}$ & $2.3 \times 10^{6}$ & $\begin{array}{l}1.7 \\
1.9\end{array}$ \\
\hline M.G. & 18 & & & & $\begin{array}{l}9.7 \\
8.5\end{array}$ & $\begin{array}{l}296 \\
278\end{array}$ & $2.3 \times 10^{6}$ & $\begin{array}{l}2.6 \\
2.8\end{array}$ \\
\hline C.Z. & 18 & & & & $\begin{array}{l}3.5 \\
1.9 \\
1.2\end{array}$ & $\begin{array}{l}348 \\
510 \\
342\end{array}$ & $2.3 \times 10^{6}$ & $\begin{array}{l}2.2 \| \\
1.5 \\
2.2\end{array}$ \\
\hline
\end{tabular}

* The production-rate assay was performed during the last 3 days of each medication period.

$\dagger$ Duplicate values represent estimates after repetition of the acetylation and saponification procedure used to isolate testosterone.

SE of counting, $7 \%$ or less.

\&E of counting, $20 \%$.

II This assay was repeated twice because of the poor initial agreement after duplication.

Theoretical considerations. The isotope-dilution method depends upon the dilution of the labeled testosterone by testosterone from all sources. When all the testosterone is secreted by the glands, then a secretion rate is obtained. If, however, a portion of the testosterone is derived from other steroids such as androstenedione as a result of peripheral metabolism, then the isotope-dilution

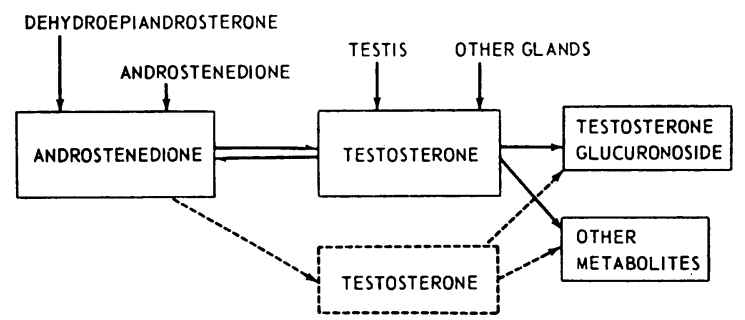

Fig. 1. A MODEL SYSTEM FOR THE PRODUCTION AND METABOLISM OF TESTOSTERONE. The upper testosterone box indicates the pool of testosterone that receives testosterone secreted by the glands and produced by the liver and other peripheral tissues. A unique metabolite of testosterone is testosterone glucuronoside, which is rapidly excreted in the urine. technique measures the total production of testosterone or the production rate.

There is considerable evidence that testosterone can be produced peripherally from other steroids. It has been shown that the dog liver perfused with dehydroepiandrosterone synthesized testosterone (26) and that oral administration of androstenedione and dehydroepiandrosterone to man resulted in higher plasma testosterone levels (27). In the elegant studies of Vande Wiele and his co-workers (21), the contributions of the dehydroepiandrosterone and androstenedione pools to the testosterone pool were measured and found to be a significant fraction of the testosterone produced. Injected, labeled testosterone is thus diluted by testosterone secreted by the glands and by that produced in peripheral tissues. Therefore the isotope-dilution technique as used in our studies measures the production rate of testosterone, not its glandular secretion rate. Only when there is no peripheral production of testosterone will the production rate equal the secretion rate. 
From these considerations, the production rate should be a better measure of the total androgen available to the individual than the secretion rate. It would be necessary, in validating this conclusion, to show that all the testosterone synthesized peripherally is actually returned to the plasma before conjugation or metabolism occurs.

Assuming that testosterone glucuronoside is physiologically inactive, one needs to know the degree to which the testosterone produced by the peripheral metabolism of androstenedione is conjugated before its entry into the general circulation. Since our measurement of testosterone production rate is based on the SA of urinary testosterone glucuronoside, we cannot distinguish between the portions of peripherally derived testosterone that either enter the plasma pool or are conjugated immediately. If this latter fraction is an appreciable portion of the urinary testosterone glucuronoside, then the testosterone production rate will overestimate the amount of testosterone reaching the plasma pool. This problem is of considerable quantitative significance in view of the demonstration (21) that in one female subject androstenedione was the major precursor of testosterone.

On the basis of these concepts, we propose a model system for the production and metabolism of testosterone (Figure 1). The dotted lines outline a hypothetical testosterone pool that is not "active androgen" because it is either conjugated or metabolized before reaching the plasma. The existence and quantitative significance of this pool can be determined only by a detailed examination of the peripheral metabolism of androstenedione. Such studies are in progress.

The assumptions upon which isotope-dilution methods for secretion rates are based have been discussed in detail by Vande Wiele, MacDonald, Bolte, and Lieberman (20). When utilizing the method for the estimation of production rates, we assumed that the injected radioactivity mixes rapidly with the single hormonal pool from which all of the excreted metabolite must come. The validity of this assumption in the testosterone production-rate assay has been discussed. We have further assumed that our rechromatographed tracer is pure, that the label is not lost during metabolism, that the fraction of hormone converted to the metabolite is constant, and that testosterone glucuronoside is uniquely derived from the testosterone pool. The finding that at least 66 to $80 \%$ of the administered isotope was excreted in the urine within 3 days supports the assumption of complete excretion of radioactivity, especially since it has been shown that 10 to $15 \%$ may appear in the stool $(19,28)$.

\section{SUM M ARY}

Testosterone production rate has been measured in normal young men and women by the isotopedilution technique using a fluorometric assay of urinary testosterone. Production rates ranged between 4 and $11.8 \mathrm{mg}$ daily in five men and between 0.9 and $2.8 \mathrm{mg}$ daily in four women. Doses of $1,000 \mathrm{U}$ of HCG to the men for 5 days and $2,000 \mathrm{U}$ to the women for 5 days significantly increased testosterone production rates. The difference between secretion and production rates has been discussed.

\section{ACKNOWLEDGMENT}

We are indebted to Drs. Raymond Vande Wiele and Seymour Lieberman for their discussions and suggestions. We wish to thank Mr. David Ryan and Mr. Alfred Bracey for their excellent technical assistance.

\section{REFERENCES}

1. Finkelstein, M., E. Forchielli, and R. I. Dorfman. Estimation of testosterone in human plasma. J. clin. Endocr. 1961, 21, 98.

2. Schubert, K., and K. Wehrberger. Isolierung von Testosteron aus Normalharn. Naturwissenschaften 1960, 47, 281.

3. Camacho, A. M., and C. J. Migeon. Isolation, identification and quantitation of testosterone in the urine of normal adults and in patients with endocrine disorders. J. clin. Endocr. 1963, 23, 301.

4. Hudson, B., J. Coghlan, A. Dulmanis, and I. Ekkel. Measurement of testosterone secretion. Proc. Endocr. Soc. 44th meeting, Chicago, 1962, p. 16.

5. Wilson, H. Absorption spectra of $\Delta^{5}-3 \beta$-hydroxy steroids in several sulfuric acid reagents. Analyt. Biochem. 1960, 1, 402.

6. Peterson, R. E., J. B. Wyngaarden, S. L. Guerra, B. B. Brodie, and J. J. Bunim. The physiological disposition and metabolic fate of hydrocortisone in man. J. clin. Invest. 1955, 34, 1779.

7. Wilson, H., J. J. Borris, and M. M. Garrison. Chromatographic procedure for the determination of urinary corticosteroids and $\mathrm{C}_{19}$ steroids. J. clin. Endocr. 1958, 18, 643. 
8. Wilson, H., M. B. Lipsett, and D. W. Ryan. Urinary excretion of $\Delta^{5}$-pregnenetriol and other $3 \beta$-hydroxy $-\Delta^{*}$ steroids by subjects with and without endocrine disease. J. clin. Endocr. 1961, 21, 1304.

9. Davidson, J. D., and P. Feigelson. Practical aspects of internal-sample liquid-scintillation counting. Int. J. appl. Radiat. 1957, 2, 1.

10. Haahti, E. Major lipid constituents of human skin surface with special reference to gas-chromatographic methods. Scand. J. clin. Lab. Invest. 1961, suppl. 59, 13.

11. Grubbs, F. E. Sample criteria for testing outlying observations. Ann. math. Stat. 1950, 21, 27.

12. Linford, J. H., and O. B. Paulson. The absorption and fluorescence properties, in the visible spectral region, of certain steroids in sulfuric acid solutions. Canad. J. med. Sci. 1952, 30, 213.

13. Goldzieher, J. W., J. M. Bodenchuk, and P. Nolan. The fluorescence reactions of steroids. Analyt. Chem. 1954, 26, 853.

14. Kalant, $H$. Chromogenic and fluorogenic reactions of adrenocortical and other steroids in concentrated acids. Biochem. J. 1958, 69, 79.

15. Bush, I. E., and M. Willoughby. The excretion of allotetrahydrocortisol in human urine. Biochem. J. 1957, 67, 689.

16. Kempthorne, O. The Design and Analysis of Experiments. New York, Wiley, 1952, p. 156.

17. Vande Wiele, R. L., and S. Lieberman. The metabolism of dehydroisoandrosterone in Biological Activities of Steroids in Relation to Cancer, G. Pincus and E. P. Vollmer, Eds. New York, Academic Press, 1960, p. 93.

18. Korenman, S. G., H. Wilson, and M. B. Lipsett. J. biol. Chem. In press.

19. Fukushima, D. K., H. L. Bradlow, K. Dobriner, and T. F. Gallagher. The fate of testosterone in- fused intravenously in man. J. biol. Chem. 1954, 206, 863.

20. Vande Wiele, R. L., P. C. MacDonald, E. Bolte, and S. Lieberman. Precursors of the urinary 11desoxy-17-ketosteroids : estimation of the secretory rate of dehydroisoandrosterone. J. clin. Endocr. 1962, 22, 1207.

21. Vande Wiele, R. L., P. C. MacDonald, E. Gurpide, and S. Lieberman. Studies on the secretion and interconversion of the androgens. Recent Progr. Hormone Res. 1962, 19, 275.

22. Maddock, W. O., and W. O. Nelson. The effects of chorionic gonadotropin in adult men: increased estrogen and 17-ketosteroid excretion, gynecomastia, Leydig cell stimulation and seminiferous tubule damage. J. clin. Endocr. 1952, 12, 985.

23. Eik-Nes, K. B. Secretion of testosterone in anesthetized dogs. Endocrinology 1962, 71, 101.

24. Gemzell, C. A., E. Diczfalusy, and C. Tillinger. Clinical effect of human pituitary follicle-stimulating hormone (FSH). J. clin. Endocr. 1958, 18, 1333.

25. Rosemberg, E., J. Coleman, M. Demany, and C-R. Garcia. Clinical effect of human urinary postmenopausal gonadotropin. J. clin. Endocr. 1963, 23, 181.

26. Klempien, E. J., K. D. Voigt, and J. Tamm. Der Umsatz von Dehydroisoandrosteron in der Hundeleber. Acta endocr. (Kbh.) 1961, 36, 498.

27. Mahesh, V. B., R. B. Greenblatt, C. K. Aydar, and S. Roy. Secretion of androgens by the polycystic ovary and its significance. Fertil. and Steril. 1962, 13, 513.

28. Sandberg, A. A., and W. R. Slaunwhite, Jr. Metabolism of 4-C $\mathrm{C}^{14}$-testosterone in human subjects. I. Distribution in bile, blood, feces and urine. J. clin. Invest. 1956, 35, 1331. 